\title{
External Application of Apo-9'-fucoxanthinone, Isolated from Sargassum muticum, Suppresses Inflammatory Responses in a Mouse Model of Atopic Dermatitis
}

\author{
Sang-Chul Han', Na-Jin Kang', Weon-Jong Yoon², Sejin Kim', Min-Chull Na', Young-Sang Koh', \\ Jin-Won Hyun', Nam-Ho Lee ${ }^{3}$, Mi-Hee Ko ${ }^{2}$, Hee-Kyoung Kang ${ }^{1}$ and Eun-Sook Yoo ${ }^{1}$ \\ ${ }^{1}$ Department of Medicine, School of Medicine, Jeju National University, Jeju, Korea \\ ${ }^{2}$ Jeju Biodiversity Research Institute (JBRI), Jeju Technopark (JTP), Jeju, Korea \\ ${ }^{3}$ Department of Chemistry, College of Natural Science, Jeju National University, Jeju, Korea
}

(Received October 20, 2015; Revised December 15, 2015; Accepted January 27, 2016)

\begin{abstract}
Allergic skin inflammation such as atopic dermatitis is characterized by skin barrier dysfunction, edema, and infiltration with various inflammatory cells. The anti-inflammatory effects of Apo-9'-fucoxanthinone, isolated from Sargassum muticum, have been described in many diseases, but the mechanism by which it modulates the immune system is poorly understood. In this study, the ability of Apo-9'-fucoxanthinone to suppress allergic reactions was investigated using a mouse model of atopic dermatitis. The Apo-9'-fucoxanthinone-treated group showed significantly decreased immunoglobulin E in serum. Also, Apo-9'-fucoxanthinone treatment resulted in a smaller lymph node size with reduced the thickness and length compared to the induction group. In addition, Apo-9'-fucoxanthinone inhibited the expression of interleukin-4, interferon-gamma and tumor necrosis factor-alpha by phorbol 12-myristate 13-acetate and ionomycin-stimulated lymphocytes. These results suggest that Apo-9'-fucoxanthinone may be a useful therapeutic strategy for treating chronic inflammatory diseases.
\end{abstract}

Key words: Apo-9'-fucoxanthinone, Atopic dermatitis, 2, 4-Dinitrochlorobenzene, Immunoglobulin E, Phorbol 12-myristate 13-acetate, Ionomycin

\section{INTRODUCTION}

Atopic dermatitis (AD) is a chronic relapsing skin disease associated with intense pruritus and skin hyper-reactivity, which affects approximately 10 20\% of children and $1 \sim 3 \%$ of adults worldwide (1). The skin lesions in AD patients are generally characterized by thickening of the papillary dermis, skin barrier dysfunction, epidermal hyperplasia, severe skin dehydration, parakeratosis, and various

Correspondence to: Eun-Sook Yoo, Department of Medicine, School of Medicine, Jeju National University, Jeju 690-756, Korea E-mail: eunsyoo@jejunu.ac.kr

Abbreviations: AD, Atopic dermatitis; DNCB, 2, 4-dinitrochlorobenzene; APO-9, Apo-9'-fucoxanthinone; IgE, Immunoglobulin E; PMA, Phorbol 12-myristate 13-acetate.

This is an Open-Access article distributed under the terms of the Creative Commons Attribution Non-Commercial License (http:// creativecommons.org/licenses/by-nc/3.0) which permits unrestricted non-commercial use, distribution, and reproduction in any medium, provided the original work is properly cited. inflammatory cells hyperproliferation, which consist mainly monocytes, mast cells, basophils and T cells (2-4).

Mast cells play an important role in allergic, innate immunity and anaphylactic reactions. Activated mast cells release a variety of inflammatory mediators such as cytokines, serotonin and histamine following cross-linking of their high affinity surface receptor (Fc3RI) for immunoglobulin E (IgE) (5-7).

$\mathrm{T}$ cells play an important role in cell-mediated immunity. Activated $\mathrm{T}$ cells can differentiate into one of several subtypes such as T-helper 1 (Th1), Th2, Th9, Th17 and regulatory $\mathrm{T}$ cell, which express different types of cytokines. Chronic $\mathrm{AD}$ is characterized by Th1-mediated immune responses. Th1 cells, regulated by the transcription factors T-box expressed in T-cells (T-bet), secrete large amounts of tumor necrosis factor-alpha (TNF- $\alpha$ ) and interferon-gamma (IFN- $\gamma$ ), which regulate the development of Th2 cells $(8,9)$. Acute AD is characterized by Th2-mediated immune responses. Th2 cells, regulated by the GATA-binding protein3 (GATA-3), express a variety of cytokines, including interleukin-4 (IL-4), IL-5, IL-6, IL-9 and IL-13, which can sup- 
press the development of Th1 cells $(10,11)$.

Recent studies have explored various marine bio-resources to investigate their active components in pharmaceutical and high nutritional value (12-14). Sargassum muticum ( $S$. muticum), a brown edible alga, is widely distributed on the Jeju coastal area. Several previous studies have examined the anti-allergic effects of Apo-9'-fucoxanthinone isolated from $S$. muticum. APO-9 can reduce the levels of nitric oxide and prostaglandin E2 (PGE2) in LPS-stimulated RAW264.7 cells, and inhibit the pro-inflammatory cytokines production and the phosphorylation of MAPKs in CpG DNA-stimulated BMDMs and BMDCs $(12,15)$. The beneficial effects of APO-9 have been described in many studies, but the mechanism by which it modulates the immune system and the allergic reactions is poorly understood. Therefore, the aim of this study was to examine whether APO-9 suppresses the various allergic inflammatory responses. The ability of APO-9 to modulate the immune system was investigated using a mouse model of AD.

\section{MATERIAL AND METHODS}

Reagents. Apo-9'-fucoxanthinone (APO-9) was provided by Professor Nam-Ho Lee (Jeju national university, Jeju, Korea; Fig. 1). Phorbol 12-myristate 13-acetate (PMA), Ionomycin and 2- $\beta$-mercaptoethanol were purchased from Sigma (St Louis, MO, USA), and TRIzol reagent was obtained from Molecular Research Center Inc (Oxford, UK). Dinitrochlorobenzene (DNCB) was purchased from Tokyo Kasei Kogyo (Tokyo, Japan). All other chemicals and reagents were of reagent grade.

Isolation of $\mathrm{CD4}^{+} \mathrm{T}$ cells and cell culture. $\quad \mathrm{CD}^{+} \mathrm{T}$ cells were isolated from the total lymphocytes population in the lymph nodes (LNs) using a Dynabeads ${ }^{\circledR}$ Untouched $^{\mathrm{TM}}$ Mouse CD4 cell kit (Invitrogen, Carlsbad, CA, USA) according to the manufacturer's instructions. Briefly, cells were incubated with an antibody mixture for $20 \mathrm{~min}$. Bead-bound cells were then incubated for $15 \mathrm{~min}$ in Dynabeads buffer. The bead-free cells were then transferred to a new tube and resuspended in fresh medium. The isolated $\mathrm{CD}^{+} \mathrm{T}$ cells were cultured in RPMI 1640 (Gibco, Uxbridge, UK) con-

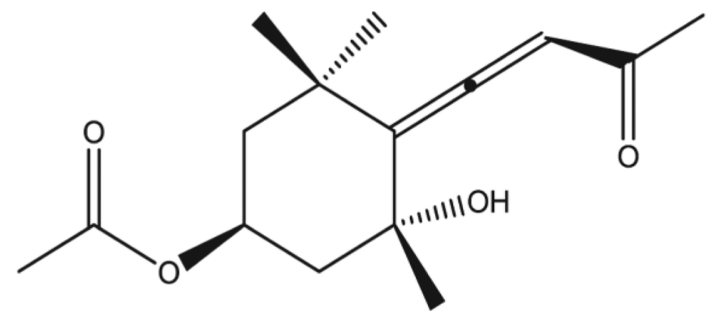

Fig. 1. Chemical structure of Apo-9'-fucoxanthinone contained in Sargassum muticum. taining L-Glutamine and $25 \mathrm{mM}$ HEPES and supplemented with $10 \%$ ( $\mathrm{vol} / \mathrm{vol}$ ) FBS (Gibco), $100 \mathrm{U} / \mathrm{mL}$ penicillinstreptomycin (Gibco), and $0.05 \mathrm{mM} 2-\beta$-mercapto-ethanol. For the cytokine analysis, isolated $\mathrm{CD}^{+} \mathrm{T}$ cells $\left(1.0 \times 10^{6}\right.$ cells $/ \mathrm{mL}$ ) were incubated in the presence or absence of PMA $(10 \mathrm{ng} / \mathrm{mL})$ and Ionomycin $(1 \mu \mathrm{g} / \mathrm{mL})$ with indicated concentrations of APO-9 $(6.25$ to $50 \mu \mathrm{M})$ for $4 \mathrm{hr}$.

Cell viability. Cell viability was determined by EZCyTox (WST-1) assays (Daeil Lab Inc., Seoul, Korea). $\mathrm{CD} 4^{+} \mathrm{T}$ cells $\left(1.0 \times 10^{6}\right.$ cells $\left./ \mathrm{mL}\right)$ were seeded on 96 -well culture plates and treated with indicated concentrations of APO-9 $(6.25$ to $50 \mu \mathrm{M})$. After incubation for $24 \mathrm{hr}$, cells were treated with $5 \mu \mathrm{L}$ of WST per well in a $5 \% \mathrm{CO}_{2}$ atmosphere incubator for $3 \mathrm{hr}$ at $37^{\circ} \mathrm{C}$. The light absorbance of each well was quantified using a VersaMax ELISA microplate reader (Molecular Devices, Sunnyvale, CA, USA) at $450 \mathrm{~nm}$.

Extraction of total RNA and real-time PCR. Total RNA was isolated using TRIzol reagent according to the manufacturer's instructions. Reverse transcription was performed using a First-Strand cDNA Synthesis kit (Promega, Madison, WI, USA). Real-time quantitative PCR was performed with a KAPA SYBR ${ }^{\circledR}$ FAST qPCR kit (Kapa Biosystems, Woburn, MA, USA) and the $\mathrm{iQ}^{\mathrm{TM}} 5$ Multicolor Real-Time PCR Detection System (Bio-Rad Laboratories, Inc.) to measure gene expression levels. The results were analyzed using $\mathrm{iQ}^{\mathrm{TM}} 5$ optical system software, which measures the amplification of the target and the endogenous control (GAPDH) in both the test and reference samples. The data were normalized using GAPDH. The following primers were used for RT-PCR: mIFN- $\gamma$ (forward: 5'-TCA AGT GGC ATA GAT GTG GAA GAA-3'; reverse: 5'-TGG CTC TGC AGG ATT TTC ATG-3'), mIL-4 (forward: 5'ACA GGA GAA GGG ACG CCAT-3'; reverse: 5'-GAA GAA CTA CAG ACG AGC TCA-3') and mTNF- $\alpha$ (forward: 5'-CAT CTT CTC AAA ATT CGA GTG ACA A-3'; reverse: 5'-TGG GAG TAG ACA AGG TAC AAC CC-3').

Experimental animals. BALB/c mice (female, 7-weeksold) were purchased from Orient Bio (Orient Bio Inc., Seongnam, Korea) and maintained under pathogen-free conditions in the animal facility of Jeju National University. All animal experiments were approved by the Jeju National University Animal Care and Use Committee.

DNCB application to induce AD. Mice were divided into four groups ( $n=5$ per group): saline (normal), AD (induction-only), $\mathrm{AD}+$ Hydrocort cream, and $\mathrm{AD}+\mathrm{APO}-$ 9. Mice were sensitized by applying $1 \%$ DNCB or vehicle on their abdomen as the first sensitization (day-7). On Day 0 , mice were challenged again by applying $0.3 \%$ DNCB to the ears on every other day for up to 30 days. Starting on 
Day 12, the mice were treated with hydrocort cream (Green Cross, Korea) containing $2 \mathrm{mg} / \mathrm{g}$ hydrocortisone valerate and APO-9 $(100 \mathrm{mg} / \mathrm{kg})$ on their ears every other day. The mice were sacrificed on day 31 .

Enzyme-linked immunosorbent assay (ELISA). The levels of IgE (Biolegend, San Diego, CA) in mouse serum were measured using ELISA kits according to the manufacturer's instructions.

Macroscopic edema and histology. In the experimental AD mouse model, DNCB stimulation elicited ear edema, and ear thickness was measured using a Digital Thickness Gauge (Mitutoyo, Kawasaki, Japan). Ear tissues were fixed in $10 \%$ formalin, and then embedded in paraffin. Paraffin sections $(3 \mu \mathrm{m}$ each) were stained with by hematoxylin and $\operatorname{eosin}(\mathrm{H} \& \mathrm{E})$.

Statistical analysis. Quantity One version 4.2.1 and Image-Pro plus version 4.5 software were used to transform images into numerical values. Student's t-test and twoway analysis of variance were used to determine the statistical significance of differences between experimental and induction groups. Data are shown as mean \pm standard devi- ation. $P$-values less than 0.05 were considered statistically significant.

\section{RESULTS}

APO-9 inhibits the production of inflammatory cytokines in $\mathrm{CD4}^{+} \mathrm{T}$ cell. The T helper cells (Th cells) play a crucial role in the immune response, and affect the activity of other immune cells by releasing cytokines. Th1 cells are the host immunity effectors and the primary source for inflammatory cytokines such as IFN- $\gamma$ and TNF- $\alpha$. Th2 cells mediate the activation of the humoral against extracellular parasites and allergens. Th2 cells are the primary source for inflammatory cytokines such as IL-4, IL-5, IL-6, IL-9 and IL-13 (16). Therefore, we measured whether APO-9 suppresses Th1 and Th 2 cytokines in $\mathrm{CD}^{+} \mathrm{T}$ cells. We determined cell viability at various concentrations of APO-9 by WST-1 assay. APO-9 is no cytotoxic at the tested concentrations (Fig. 2A). Next, we examined the effect of APO-9 on the production of IL-4, IFN- $\gamma$ and TNF- $\alpha$ in $\mathrm{CD} 4+\mathrm{T}$ cells. $\mathrm{CD}^{+} \mathrm{T}$ cells were incubated in the presence or absence of PMA $(10 \mathrm{ng} / \mathrm{mL})$ and Ionomycin $(1 \mu \mathrm{g} / \mathrm{mL})$ with indicated concentrations of APO-9 (6.25 to $50 \mu \mathrm{M})$ for $4 \mathrm{hr}$, and were measured by real-time PCR. APO-9 inhib-

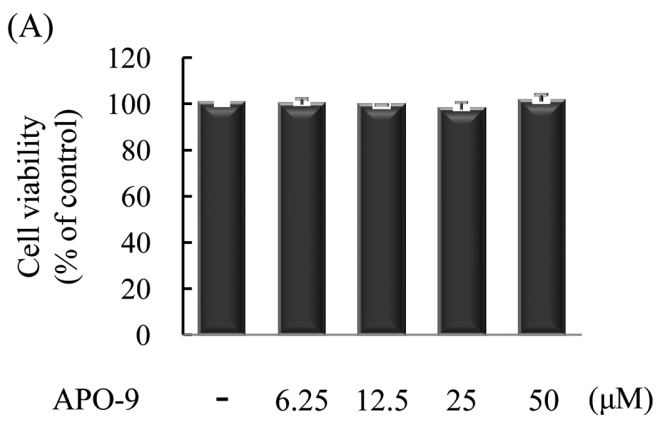

(B)

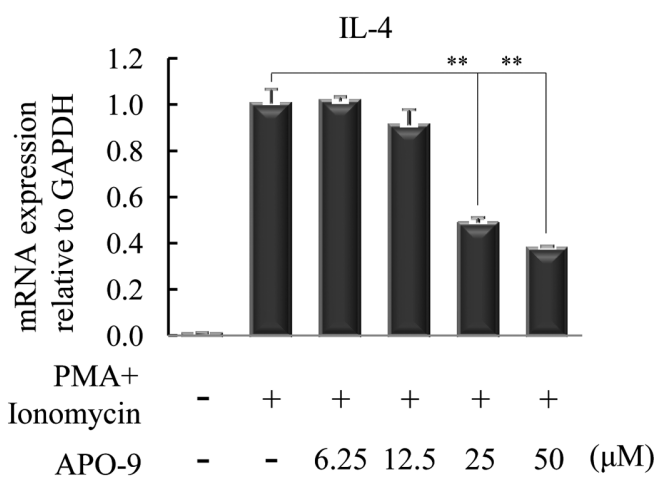

(C)

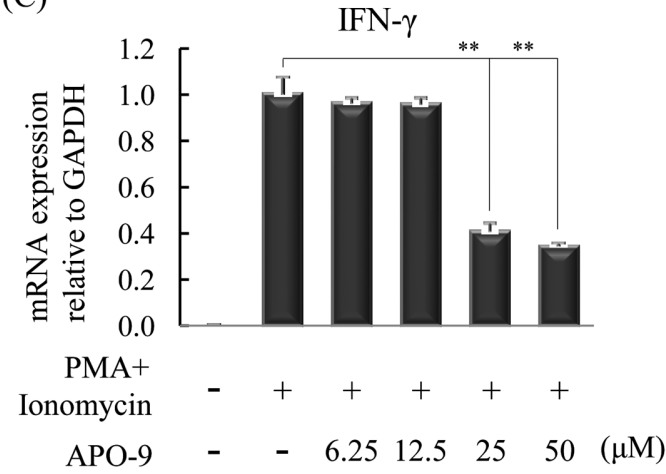

(D)

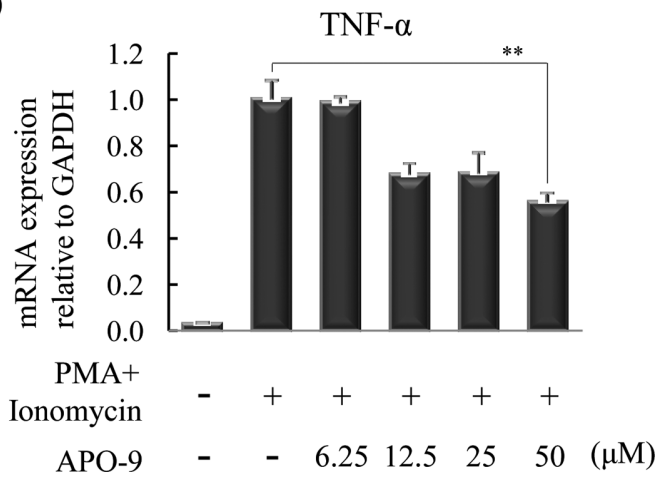

Fig. 2. Apo-9'-fucoxanthinone suppresses the expression of various cytokines in $\mathrm{CD}^{+}{ }^{+} \mathrm{T}$ cells. CD4 ${ }^{+} \mathrm{T}$ cells $\left(1.0 \times 10^{6} \mathrm{cell} / \mathrm{s} / \mathrm{mL}\right)$ isolated from lymphocytes were incubated in the presence or absence of PMA $(10 \mathrm{ng} / \mathrm{mL})$ and ionomycin $(1 \mu \mathrm{g} / \mathrm{mL})$ with indicated concentrations of APO-9 $(6.25$ to $50 \mu \mathrm{M}$ ) for 4 (real-time PCR) or 24 (WST-1 assay) hours. (A) Cell viability was analyzed by WST-1 assay. (B-D) The expression of mRNA for various cytokines in $C D 4^{+} T$ cells was measured by real-time PCR. The measurements were made in triplicate and are shown as mean \pm S.D. ${ }^{* *} P<0.01$ compared to $C D 4^{+} T$ cells with PMA/ionomycin alone. 
ited the production of IL-4, IFN- $\gamma$ and TNF- $\alpha$ in a dosedependent manner, compared with the control (Fig. 2B-2D).

APO-9 suppresses the expression of serum IgE. To induce experimental $\mathrm{AD}$, mice were stimulated an initial sensitization with $1 \%$ DNCB on the abdomen. They were then resensitized by applying $0.3 \%$ DNCB to the ears on every other day for up to 41 days. Starting on day 12, the mice were received with hydrocort cream and APO-9 $(100 \mathrm{mg} / \mathrm{kg})$ on their ears every other day. On day 31 , all mice were sacrificed (Fig. 3A). IgE is a crucial therapeutic target for $\mathrm{AD}$, as it is the major activator of mast cells, which release histamine, tryptase and cytokines (17). Therefore, we measured the levels of serum $\operatorname{IgE}$ in mice with dermatitis by ELISA. The APO-9-treated group showed significantly decreased levels of $\operatorname{IgE}(P<0.05)$ compared with the induction group (mice exposed to DNCB but not treated APO-9; Fig. 3B).

APO-9 suppresses the development of experimental AD. The skin lesions associated with $\mathrm{AD}$ are characterized by infiltration of various inflammatory cells (18).

(A)

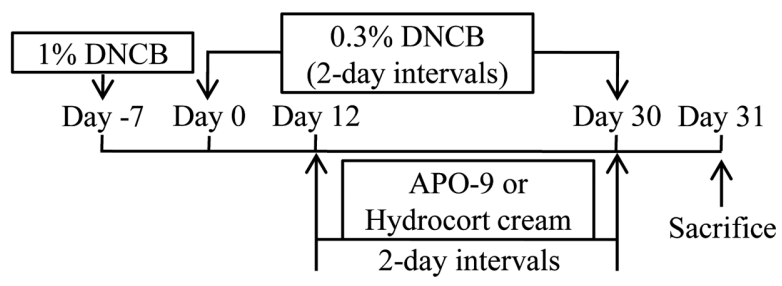

(B)

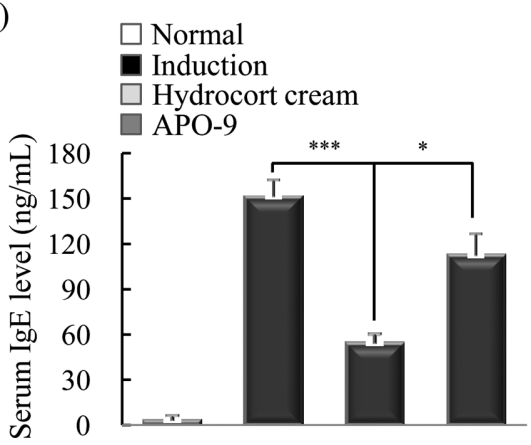

Fig. 3. Apo-9'-fucoxanthinone suppresses the expression of serum IgE. (A) Mice were sensitized by applying 1\% DNCB or vehicle on their abdomen as the first sensitization (day-7). On Day 0 , mice were challenged again by applying 0.3\% DNCB to the ears on every other day for up to 30 days. Starting on Day 12 , the mice were treated with hydrocort cream and APO-9 $(100 \mathrm{mg} / \mathrm{kg})$ on their ears every other day. The mice were sacrificed on day 31. (B) After sacrifice, the IgE in mouse serum was measured by ELISA. Data are representative of 5 mice per group ( $\mathrm{n}=5$ mice per group). Values represent the mean $\pm \mathrm{SD}$. ${ }^{*} P<$ 0.05 ; ${ }^{* *} P<0.001$ compared to mice stimulated with $D N C B$ alone (induction group).
Therefore, we measured whether APO-9 treatment alleviates the level of inflammatory cell infiltration in the ears of mice with experimental AD. We also tested skin swelling as a measure of $\mathrm{AD}$ progression. We found that the cutaneous edema in APO-9-treated mice was reduced at days $29(P<$ $0.05)$ compared with that observed in the induction-only mice (Fig. 4A, 4B). We next examined the effect of APO-9 on the infiltration of inflammatory cells by H\&E staining of ear tissue sections. Epidermal thickness and the degree of inflammatory cell infiltration were significantly lower in the APO-9-treated group than in the induction group (Fig. 4C). The LNs have a crucial role in cell-mediated immunity by regulating the activity of $\mathrm{T}$ and $\mathrm{B}$ cells (19). Therefore, we tested the morphologic changes in the LN of experimental $\mathrm{AD}$. The LNs from mice in the induction-only group were very swollen, whereas those from APO-9-treated mice were smaller (Fig. 4D).

\section{DISCUSSION}

In this study, we determined APO-9's ability to suppress the various inflammatory responses. APO- 9 treatment potently modulates the immune system. AD mainly appears with various diseases such as rhinitis, allergic conjunctivitis and asthma $(1,2)$. In the present study, we utilized the DNCBstimulated $\mathrm{AD}$ mouse model to investigate the anti-inflammatory effect of APO-9. Th1 cells are the primary source for inflammatory cytokines such as IFN- $\gamma$ and TNF- $\alpha$, and transcription factors T-bet is important for the differentiation of Th1 cells (16). Th2 cells express a variety of cytokines, such as IL-4, $-5,-6$ and -13 , and preferentially express GATA3, which is crucial for Th2 differentiation $(20,21)$. We measured whether APO-9 treatment regulate the expression of Th1/Th2 associated cytokines in experimental AD. APO-9 reduced the mRNA levels of IL-4, IFN- $\gamma$ and TNF$\alpha$. IgE is an important therapeutic target for allergy, and signaling through FceRI can release histamine, tryptase and cytokines from mast cells, which leads to potent induction of edema or itching $(22,23)$. Therefore, we tested whether APO-9 can decrease serum IgE hyper-production and cutaneouse edema. The APO-9 treatment reduced the levels of $\mathrm{IgE}$ and edema compared with the induction-only group. H\&E staining of the ear tissue showed that APO-9 treatment alleviated the infiltration of inflammatory cells compared with the induction-only group. The LNs play an important role in regulating the immune responses and contains a variety of immune cells. Also, enlared LN means a lymph node-enlargement by abnormality of immune system (24). We investigated the morphologic features of the LNs in experimental AD model. The induction-only group had markedly enlarged LNs; the LNs from APO-9-treated mice were smaller compared with those from mice in the induction-only group. In summary, APO-9 had strong inhibitory effects on various $\mathrm{AD}$ symptoms. It is not yet clear why 


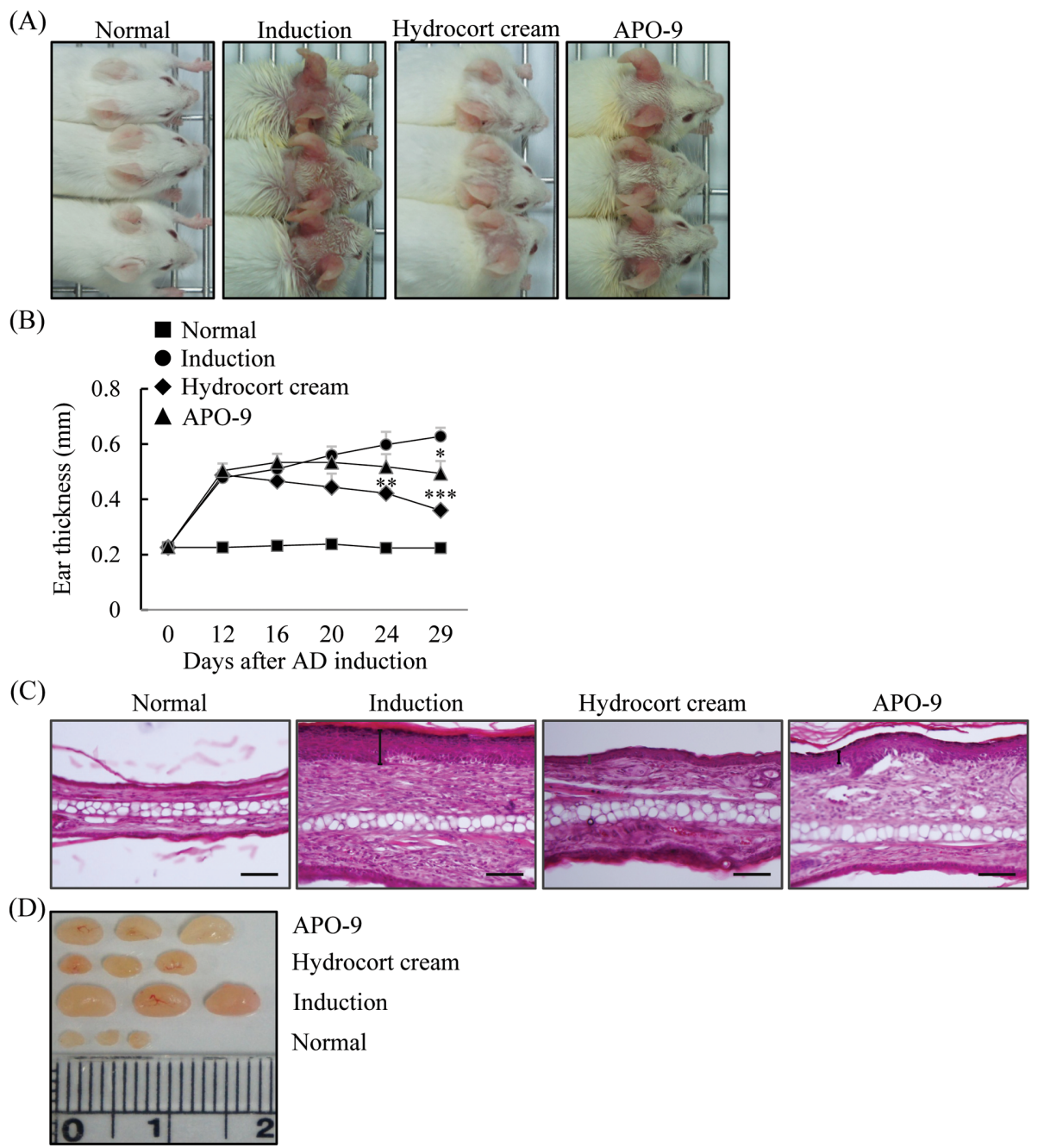

Fig. 4. Apo-9'-fucoxanthinone suppresses experimental atopic dermatitis. (A) Macroscopic views of the ears and (B) ear thickness measured on days $0,12,16,20,24$, and 29. (C) Paraffin-embeded sections of ear tissue stained with hematoxylin and eosin. (D) The lymph nodes (LNs) were photographed to record morphologic changes $(n=5$ mice per group). Scale bar $=0.1 \mathrm{~mm}$. Values represent the mean \pm SD. ${ }^{*} P<0.05 ;{ }^{* *} P<0.01$ and ${ }^{* *} P<0.001$ compared to mice stimulated with DNCB alone (induction group).

APO-9 has strong immunomodulatory effects. So we are currently trying to identify the inter-relationships between APO-9 and regulatory $\mathrm{T}$ cells. Our results suggest that the Apo-9'-fucoxanthinone may be a useful therapeutic strategy for the allergic symptoms of AD.

\section{ACKNOWLEDGEMENTS}

This research was supported by the National Research Foundation of Korea Grant funded by the Korean Government (Ministry of Education, Science and Technology; MEST) (NRF-C1ABA001-2011-0021039).

\section{CONFLICT OF INTEREST}

The authors state no conflict of interest.

\section{REFERENCES}

1. Leung, D.Y., Boguniewicz, M., Howell, M.D., Nomura, I. and Hamid, Q.A. (2004) New insights into atopic dermatitis. J. Clin. Invest., 113, 651-657.

2. Li, C., Lasse, S., Lee, P., Nakasaki, M., Chen, S.W., Yamasaki, K., Gallo, R.L. and Jamora, C. (2010) Development of atopic dermatitis-like skin disease from the chronic loss of epidermal caspase-8. Proc. Natl. Acad. Sci. U.S.A., 107, 22249-22254.

3. Nystad, W., Roysamb, E., Magnus, P., Tambs, K. and Harris, J.R. (2005) A comparison of genetic and environmental variance structures for asthma, hay fever and eczema with symptoms of the same diseases: a study of Norwegian twins. Int. $J$. Epidemiol., 34, 1302-1309.

4. Wahlgren, C.F. (1999) Itch and atopic dermatitis: an overview. J. Dermatol., 26, 770-779. 
5. Kawakami, T., Ando, T., Kimura, M., Wilson, B.S. and Kawakami, Y. (2009) Mast cells in atopic dermatitis. Curr. Opin. Immunol., 21, 666-678.

6. Kitamura, Y. and Ito, A. (2005) Mast cell-committed progenitors. Proc. Natl. Acad. Sci. U.S.A., 102, 11129-11130.

7. Leitges, M., Gimborn, K., Elis, W., Kalesnikoff, J., Hughes, M.R., Krystal, G. and Huber, M. (2002) Protein kinase C- $\delta$ is a negative regulator of antigen-induced mast cell degranulation. Mol. Cell. Biol., 22, 3970-3980.

8. Glimcher, L.H. and Murphy, K.M. (2000) Lineage commitment in the immune system: the $\mathrm{T}$ helper lymphocyte grows up. Genes Dev., 14, 1693-1711.

9. Ouyang, W., Ranganath, S.H., Weindel, K., Bhattacharya, D., Murphy, T.L., Sha, W.C. and Murphy, K.M. (1998) Inhibition of Th1 development mediated by GATA-3 through an IL-4independent mechanism. Immunity, 9, 745-755.

10. Romagnani, S. (2000) The role of lymphocytes in allergic disease. J. Allergy Clin. Immunol., 105, 399-408.

11. Elson, C.O., Cong, Y., Brandwein, S., Weaver, C.T., McCabe, R.P., Mähler, M., Sundberg, J.P. and Leiter, E.H. (1998) Experimental models to study molecular mechanisms underlying intestinal inflammation. Ann. N. Y. Acad. Sci., 859, 85-95.

12. Chae, D., Manzoor, Z., Kim, S.C., Kim, S., Oh, T.H., Yoo, E.S., Kang, H.K., Hyun, J.W., Lee, N.H., Ko, M.H. and Koh, Y.S. (2013) Apo-9'-fucoxanthinone, isolated from Sargassum muticum, inhibits CpG-induced inflammatory response by attenuating the mitogen-activated protein kinase pathway. Mar. Drugs, 11, 3272-3287.

13. Han, S.C., Kang, G.J., Ko, Y.J., Kang, H.K., Moon, S.W., Ann, Y.S. and Yoo, E.S. (2012) External application of fermented olive flounder (paralichthys olivaceus) oil alleviates inflammatory responses in 2,4-dinitrochlorobenzene-induced atopic dermatitis mouse model. Toxicol. Res., 28, 159-164.

14. Jo, W.S., Choi, Y.J., Kim, H.J., Nam, B.H., Lee, G.A., Seo, S.Y., Lee, S.W. and Jeong, M.H. (2010) Methanolic extract of asterina pectinifera inhibits LPS-induced inflammatory mediators in murine macrophage. Toxicol. Res., 26, 37-46.

15. Yang, E.J., Ham, Y.M., Lee, W.J., Lee, N.H. and Hyun, C.G.
(2013) Anti-inflammatory effects of apo-9'-fucoxanthinone from the brown alga, Sargassum muticum. Daru, 21, 62.

16. Miyagaki, T., Asano, Y., Shibata, S., Ohno, Y., Tsunemi, Y., Saeki, H., Tamaki, K. and Sato, S. (2011) The development of Th1-mediated sarcoidosis improves the clinical course of Th2mediated atopic dermatitis. Mod. Rheumatol., 21, 406-409.

17. Levin, T.A., Ownby, D.R., Smith, P.H., Peterson, E.L., Williams, L.K., Ford, J., Young, P. and Johnson, C.C. (2006) Relationship between extremely low total serum IgE levels and rhinosinusitis. Ann. Allergy Asthma Immunol., 97, 650652.

18. de Vries, I.J., Langeveld-Wildschut, E.G., van Reijsen, F.C., Bihari, I.C., Bruijnzeel-Koomen, C.A. and Thepen, T. (1997) Nonspecific T-cell homing during inflammation in atopic dermatitis: expression of cutaneous lymphocyte-associated antigen and integrin $\alpha \mathrm{E} \beta 7$ on skin-infiltrating $\mathrm{T}$ cells. J. Allergy Clin. Immunol., 100, 694-701.

19. Debes, G.F., Bonhagen, K., Wolff, T., Kretschmer, U., Krautwald, S., Kamradt, T. and Hamann, A. (2004) CC chemokine receptor 7 expression by effector/memory $\mathrm{CD}^{+} \mathrm{T}$ cells depends on antigen specificity and tissue localization during influenza A virus infection. J. Virol., 78, 7528-7535.

20. Szabo, S.J., Kim, S.T., Costa, G.L., Zhang, X., Fathman, C.G. and Glimcher, L.H. (2000) A novel transcription factor, T-bet, directs Th1 lineage commitment. Cell, 100, 655-669.

21. Zheng, W. and Flavell, R.A. (1997) The transcription factor GATA-3 is necessary and sufficient for Th2 cytokine gene expression in CD4 T cells. Cell, 89, 587-596.

22. Schwartz, L.B. (2004) Effector cells of anaphylaxis: mast cells and basophils. Novartis Found. Symp., 257, 65-74.

23. Stone, K.D., Prussin, C. and Metcalfe, D.D. (2010) IgE, mast cells, basophils, and eosinophils. J. Allergy Clin. Immunol., 125, S73-S80.

24. Singer, P.A., McEvilly, R.J., Noonan, D.J., Dixon, F.J. and Theofilopoulos, A.N. (1986) Clonal diversity and T-cell receptor $\beta$-chain variable gene expression in enlarged lymph nodes of MRL-lpr/lpr lupus mice. Proc. Natl. Acad. Sci. U.S.A., 83, 7018-7022. 